\title{
Visual arts and cultural mediation in the Modern Art Centre of Calouste Gulbenkian Foundation
}

Camila Yuri Brito Honda milahonda@gmail.com José Pedro Barbosa Gonçalves de Bessa pbessa@ua.pt

ID+ Research Institute for Design and Media Culture, Universidade de Aveiro, Portugal

\section{Reference}

Honda, Camila Yuri Brito; Bessa, José Pedro Barbosa Gonçalves de; (2012) "Visual arts and cultural mediation in the Modern Art Centre of Calouste Gulbenkian Foundation", p. 273-277 . In: Barbosa, Helena; Quental, Joana [Eds]. Proceedings of the 2nd International Conference of Art, Illustration and Visual Culture in Infant and Primary Education São Paulo: Blucher, 2015. ISSN 2318-695X, ISBN: 978-989-98185-0-7

DOI 10.5151/edupro-aivcipe-52

Resumen

Palabras clave

Abstract

Keywords
Este artículo es resultado de un proceso de evaluación cualitativa que ha involucrado a las actividades desarrolladas por el sector educativo del Centro de Arte Moderno de la Fundación Calouste Gulbenkian. Con la observación directa de las diversas actividades, el estudio asocia los resultados obtenidos (en el nivel de la satisfacción del público acerca de la experiencia in loco), à la metodología de mediación cultural y educación museal que explora la cultura visual, el aprendizaje lúdico y la ilustración en el contexto de la educación a lo largo de la vida y del paradigma postmoderno en educación artística.

Fundación Calouste Gulbenkian, Mediación cultural, Educación museal.

This article is the result of a process of qualitative assessment that has involved activities developed by the educational sector of the Modern Art Centre of the Calouste Gulbenkian Foundation. With direct observation of several activities, the study associates the results obtained (in what concerns public satisfaction with the experience in loco), with the cultural mediation and museum education methodology activities that explore visual culture, playful learning and illustration in the context of the lifelong learning and the postmodern paradigm in art education.

Calouste Gulbenkian Foundation, Cultural mediation, Museum education.

\section{The postmodern model in museum and art education}

Hernandez (2009) tells us that the idea of cultural identity is not without determinism and that in this sense, education has always been configured around the identity in the realm of "what we should be, what we should think, than we should do"; it is also an important tool in the possibility of reinventing ourselves.

Studies on visual culture help us to think about our identities and cultural contexts and have been incorporated into arts education, highlighting the influence of images in our thoughts, our actions and feelings, the way we interpret, give meaning and relate ourselves to the world around us.

In this sense, Hernandez (2007) proposes a "different direction" for the visual arts education, suggesting a cultural approach to visual representations, considering that an educational experience, when concern with approaching the "cultural sites" the individual, i.e. his/her cultural references, can help in the construction his/her "experiences of subjectivity". Just as Paulo Freire (1987) pointed to the need for social contextualism and the "restoration of intersubjectivity" in education. These two scholars also point to a break with the dualistic discourse 
2nd International Conference Art, Illustration and Visual Culture in Infant and Primary Education esso Internacional

de Arte, llustração e Cultura Visual

na Educação Infantil e Primária

"oppressor X oppressed" or "sender / receiver" so that teaching and learning may function as a shared construction of knowledge.

The Relational Aesthetics, defended and observed by Bourriaud (2009) in the contemporary art context, performs experiments that are characterized by an enhanced relationship between art work and viewer. Instead of a mere encounter between a viewer and an object / art work, relational art promotes "inter-subjective meetings", in which the meanings are made collectively. The subjectivity gains special relevance and joins a interpretation process that, as mentioned by Ana Mae and Rejane Coutinho (2004) mention, "significa conseguir sintonizar toda a realidade de uma forma através da feliz adequação entre um dos seus aspectos e a perspectiva pessoal de quem a olha".

The field of museum education, particularly post-modern, has been consolidating constructivist theories on learning, even if Juanola and Colomer (2005) refer three educational frames that still coexist in museums in the 21th century: The traditional museum, where the educational function becomes an enhancement to convey the curator's speech to the visitor; the modern museum, which sees the educator as someone in charge of developing various types of activities to a wide audience as a way to gain visitors / consumers; and, finally, the "postmuseum" (posmuseo), where the educational task is to develop alternative discourses to the exhibitions, seeing the visitors as active individuals in the construction of knowledge and especially understanding the educational function as the core of the museum.

The mediator establishes, facilitates and leads the public's relation with art during the experience time of contact with the art work. In a process that involves being in between the parties, he/she takes different positions depending on situations like those described by Juanola and Colomer (2005), with his/her particularities as individual and professional and the public characteristics, with its individuals references and prior motivations, conducting unique experiences of negotiation meanings.

In postmodernism there is a clear change in the way we relate to art and position ourselves in relation to it. The new paradigm of cultural approach to the visual representations exists, as stated by Hernández (2009: 17), "(...) não para falar do que 'se vê' na verdade da representação, mas para reconhecer como cada um 'se vê' e é colocado em práticas de discurso".

\section{The Calouste Gulbenkian Foundation and the Modern Art centre through the ages and the challenges}

The Calouste Gulbenkian Foundation, of private law and public utility, has its headquarters in Lisbon and, along its more than 50 years of existence, came to be regarded sometimes as the "state within a state" or the "true ministry " of culture and education in Portugal (Barreto, 2006). Its public (in general, educated, informed and with an economic and education level and well above the average of the population), classifies it in an intermediate position in what concerns the categories of "too popular or too elitist" and "too conservative or too avantgarde."

The educational program DESCOBRIR publishes biannually two brochures of programming, one for schools and organized groups and one for the general public, with activities such as visits, workshops, courses and musical performances, under various formats, schedules and lengths, and covering a wider public, from babies to senior public.

The cultural mediation at the CAM goes back to the 1980s when, in the Department of Animation, Creation and Education through Art (ACARTE), began the activities of the Children's Art Centre (CAI). The CAl used to promote training courses for monitors, exhibitions and various activities for children and adult audiences. Its closure marks the closing of a cycle of 20 years of workshop practices engaged in the ideals of Education through Art. The inauguration of the educational sector of the CAM marks a clear shift in the structural strategy of the programming, which now has a much more direct connection with the permanent collection and the temporary exhibitions at the Modern Art Centre. The initiatives, as Antonio Pinto Ribeiro (2006) refers, came to be "more oriented to the creation of activities and communication with the public, and the spaces of interpretation." 
$2^{\text {nd }}$ International Conference Art, Illustration and Visual Culture in Infant and Primary Education $2^{\circ}$ Congreso Internaciona

Arte, Ilustración y Cultura Visual en Educación Infantil y Primaria
Congresso Internacional

de Arte, llustração e Cultura Visual

na Educação Infantil e Primária

The public evaluates with a very positive rate the activities promoted by the DESCOBRIR program. In the case of children's activities at the Centre of Modern Art, the percentage of children who liked the monitors or the workshops was above 90\% in all activities. The vast majority of children already had participated in other activities of DESCOBRIR, and over 90\% replied that they were willing to participate in new workshops (Honda, 2011). This information points to the excellence of the activities offered by the program and indicates the loyalty of the public who, as Barreto (2006) states is more active culturally than the Gulbenkian Museum and the Music Department.

The activities at the CAM, not only led the participants to temporary exhibitions and the permanent collection of Modern Art Centre, but also to the Gulbenkian Museum, the central building, e.g. to the photography exhibition Fronteiras, in the Next Future program, and the gardens of the Foundation; thus, valuing audience-crossing between different sectors and areas of the Calouste Gulbenkian Foundation and providing broader perspectives and experiences in terms of visual arts.

Starting always with a dynamic presentation of all participants, including monitors, the close relationship established with the children was a facilitator of dialogue and sharing moments in the construction of knowledge involved in learning experiences.

In all the activities, the awakening of curiosity was present. I remember the moment when, with the lights off, at the workshop Percursos viajantes, children worked in the process of photographic developing the image, and one at a time, manipulated the photographic paper for revelation. The images would reveal the objects that each child had chosen to secretly take in his/her suitcase. Afonso (nine years) said "I know, I know! Must be something to confuse us! "And after the first frame developed, Marguerite (seven years) said" This is a fantastic experience. "
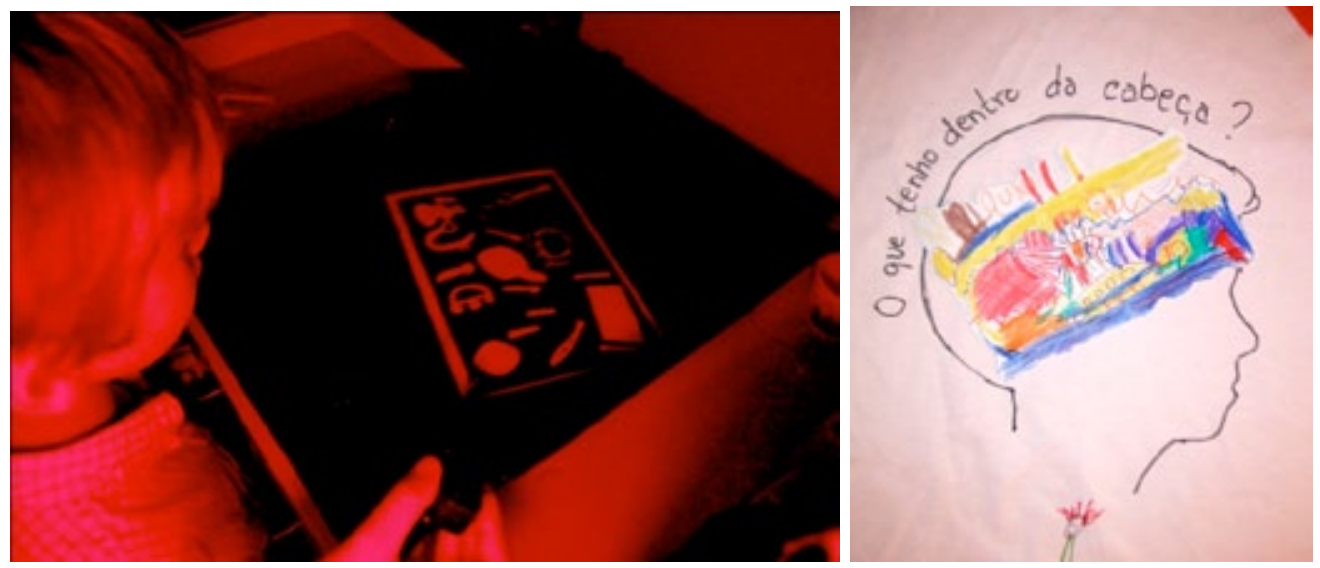

Being always established a relationship with the temporary exhibitions or the permanent collection, in each workshop the trip to the museum took place in different ways, allowing children to participate in various workshops, also to have different perspectives on the exhibition, the works of art, the artists and, in a broader sense, on the very idea of art, coupled with subjectivity.

In the workshop "A sombra das palavras", held at the temporary exhibition of João Penalva, at the CAM, the group received at first, a "surprise message" from the artist, with reproduction of one of his works on display (one scene in black and white). From this work, which led to the theme of the workshop, numerous recreational activities were developed together. The João Penalva's picture was reproduce by the children in a large color-panel, where they draw and added several elements, giving many features to the characters from the early work and building the plot which was later staged in a theater of shadows made with puppets fabricated during the story telling sessions. The story was recorded with the participation of every child from the group. In this workshop, when visiting the museum, we walked through the permanent collection in tracks drawn by lot, about the works of art. 
$2^{\text {nd }}$ International Conference Art, Illustration and Visual Culture in Infant and Primary Education

In the "Perguntas no Ar" workshop - where the comment "the best school in the world" was registered in one of the surveys - the curiosity and pleasure of the learning experiences constituted memorable moments vis-à-vis the art works. Moments of dialogue, shared construction of knowledge and memories about the works visited registered (by writing or drawing) in notebooks called "diários de bordo". I describe one of these moments, in the following:

\begin{abstract}
The children, wrapped in a storyline about trips to the sea, were conducted to the museum bearing his "logbooks", towards "a port that is not real, it's surreal." Faced with the first picture, the monitor questions the children about what they see in that painting. At first there were no answers, then she says it looks like a storm and asks "Do the sailors sleep well at night?", "Do they have nightmares during storms?" Ricardo (ten years) immediately responds, "If I was one of them, I would not be afraid!" Amidst the dialogue, questions arise, such as "But did it really happened?", and it is the opportunity for monitors to give back other questions like "Do storms really happen?", "Is it only in our dreams?" A child said that it only happens in nightmares. And when they are asked about the next picture, Beatriz (eight years) immediately says: "It looks like dreams" and then the monitors ask them which of them draw their own dreams. The dialogue continues about the adjacent works. One of the pictures had been recognized by a child as the sea bottom, and then the monitors asked what would be happening "up there", which raised several possibilities. They resume the initial question that led them to the museum, asking, "So, is it real art or rather a surreal art?"
\end{abstract}

The example above depicts the children's feedback, incorporated in the learning process, which was a constant in all the workshops offered by the CAM. It is but a small excerpt from a workshop lasting a total of 15 hours. As refers Susana Gomes da Silva (2006: 10-11), coordinator of the education sector of the CAM, the current paradigm of arts education, i.e. the postmodern or "post-museum" means "(...) uma perspectiva epistemológica que concebe o conhecimento como sendo uma produção subjectiva (enquanto construção dos sujeitos) e a aprendizagem como um rico e complexo processo contextual de interpretação".

\title{
Conclusion
}

This article briefly describes, from an internship experience at the Calouste Gulbenkian, how the relationship between public and contemporary art works, especially in children, at the Modern Art Centre, and the philosophy which inspires the Foundation calendar.

The CAM activities articulate a broad intersection of different knowledge, providing very significant experiences at the level of training throughout life. Involving the participants in an atmosphere of curiosity, pleasure and shared construction of knowledge, they constitute a very special job, carrying the postmodern paradigm of art education and museum education into the various levels of their diverse calendar.

Once, during an informal conversation between the Portuguese, by saying that I was starting an internship at the Calouste Gulbenkian Foundation, I heard "Oh, the Gulbenkian Foundation is a breath of fresh air!" At that moment I completely agreed, and in the end of my traineeship, after daily attend the Foundation and many of its activities, I do not hesitate saying that I keep this same feeling.

\section{Bibliographical references}

Barbosa, Ana Mae; Coutinho, Rejane (2004). "Diálogo e Reflexão: uma Proposta de Mediação" In Brasil, Centro Cultural Banco do. Diálogos e reflexões - Ver e perceber a arte, 6-11. São Paulo: Banco do Brasil.

Barreto, António (2006). "A Fundação Gulbenkian e a sociedade Portuguesa” In Fundação Calouste Gulbenkian: Cinquenta anos 1956-2006. Lisboa: Fundação Calouste Gulbenkian.

Bourriaud, Nicolas (2009). Estética relacional. Traduzido por Denise Bottmann. São Paulo: Martins Fontes.

Comissão europeia (2003). Validation of Non-Formal and Informal Learning: Contribution of the Comission Expert Group (Progress Report). Acedido em 15 de setembro de 2011. http://ec.europa.eu/ education/policies/2010/doc/infonational2004.pdf. 
Faria, Margarida Lima de. (2007). "Avaliação" In Barriga, Sara; Silva, Susana Gomes da (coord.) Serviços educativos na cultura, 67-77. Porto: Setepés.

Foster, Hal. (1982). "Asunto: Post” In Walliz, Brian (ed.) Arte despues de la modernidad - Nuevos planteamientos en torno a la representación, 190-201. Madrid: AKAL.

Freire, Paulo (1987). Pedagogia do oprimido, $17^{\circ}$ ed. Rio de Janeiro: Paz e Terra.

Gulbenkian, Fundação Calouste. 2004. Fundação Calouste Gulbenkian. Lisboa: Fundação Clouste Gulbenkian.

Hernández, Fernando (2007). Catadores da Cultura Visual - proposta para uma nova narrativa educacional. Porto Alegre: Editora Mediação.

Hernández, Fernando (2009). "Conferencia de Prensa en las instalaciones del Centro Cultural de España (CCE)" In Cultura, conocimiento y poder. Montevideo: Comisión Asesora en Educación y Arte del MEC. Acedido em 11 de setembro de 2011. http://webcache.googleusercontent.com/ search?q=cache:_W_b7KtuyskJ:www.uruguayeduca.edu.uy/Portal.Base/Web/verContenido.aspx \%3FID\%3D208243+fernando+hernandez+porque+cultura+conocimiento+y+poder\&cd=2\&hl=ptPT\&ct=clnk\&gl=pt.

Honda, Camila Yuri Brito (2011). Mediar a arte - o programa Desobrir da Fundação Calouste Gulbenkian. Dissertação de mestrado. Aveiro: Universidade de Aveiro.

Juanola, Roser; Colomer, Anna (2005). "Museos y educadores: perspectivas y retos de futuro" In Huerta, Ricard; Romà, Calle de la (ed.) La mirada inquieta-Educación artística y museos. València: Universitat de València.

Martinho, Teresa Duarte (2007). Apresentar a Arte: Estudo sobre monitores de visitas a exposições. Lisboa: Observatório das Actividades Culturais.

Parsons, Michael J. (1999). "Mudando direções na arte-educação contemporânea" In Compreender a Arte: um ato de cognição verbal e visual (V Encontro). São Paulo: SESC. Acedido em 17 de outubro de 2011. http://www.sescsp.org.br/sesc/hotsites/arte/text_5.htm.

Quinet, Patrick (1992). "Voyage à travers La créativité" In ACARTE, Educação pela Arte - Pensar o futuro, 103-109. Lisboa: Fundação Calouste Gulbenkian.

Santos, Arquimedes da Silva. 1998. Mediações Arteducacionais. Lisboa: Fundação Calouste Gulbenkian.

Silva, Susana Gomes da. (2006). "Para além do olhar: a construção e negociação de significados a partir da educação museal”' In Calaf, Roser; Fontal, Olaia (coords.), 2006, Miradas AL Patrimonio, 107-124. Gijón: Ediciones Trea, S. L.

Silva, Susana Gomes da. (2007). "Enquadramento teórico para uma prática educativa nos museus" In Barriga, Sara; Silva, Susana Gomes da (coord.) Serviços educativos na cultura, 57-66. Porto: Setepés. 